\title{
Food Habits of the Otter in the Central Sierra Morena (Cordoba, Spain) ${ }^{1}$
}

\author{
Pedro LOPEZ-NIEVES \& José A. HERNANDO Casal
}

\begin{abstract}
López-Nieves P. \& Hernando J. A., 1984: Food habits of the otter in the Central Sierra Morena (Cordoba, Spain). Acta theriol., 29, 32: 383-401 [With 4 Tables \& ' 7 igs.]

The food habits of the otter Lutra lutra (Linnaeus, 1758) have been studied by the analysis of their faeces in both: Guadelmez and Cuzna rivers, in Sierra Boyera Reservoir, and a stream called Garcia, all situated in the Central Sierra Morena. The diet varies little, being composed of six main categories of prey listed here in order of importance in the diet: fish amphibians, reptiles, insects, birds and mammals. In four zones studied, the existence of seasonal variations in the diet has been observed. During the wet season, fish constitute the principal nutritional source but then lose importance when contrasted with the rest of the prey found in the low period. The changing of the season, as made clear by the Principal Components Analysis (PCA). is shown to be marked in the rivers than in the reservoir. In the same way local variation which existed chiefly between the food in the two rivers and in the reservoir and corroborated by the PCA and Stepwise Discriminant Analysis (SDA) were observed. The composition of the diet is principally influenced by the availability of the resources and the preference which the otter has towards certain species.

[Departamento de Zoologia, Facultad de Ciencias, Universidad de Córdoba, Córdoba, España]
\end{abstract}

\section{INTRODUCTION}

The study in Europe of the otter's food, Lutra lutra (Linnaeus, 1758) by the examination of the food remains found in their excrements has been carried out in several habitats: in Sweden (Erlinge, 1967, 1968, 1969), in Ireland (Fairley, 1972; Fairley \& Wilson, 1972) and in Great Britain (Stephens, 1957; Hewson, 1973; Webb, 1975; Jenkins et al., 1979; Jenkins \& Harper, 1980; Mason \& Mac Donald. 1980 and Wise et al., 1981) amongst others.

The bibliography about the otter's diet on the Iberian Peninsula is very limited. At the present time the only work which contributes quantitative and qualitative data based on the analysis of digestive tracts and excrements is that carried out in Galicia (the NW of the Peninsula) by Callejo et. al. (1979).

In view of such a limited bibliography the prime objective of the

1 This paper has been granted by C.A.I.C.Y.T. No. 237/81. 
present study, was to determine the otter's diet, in a zone where its existence could apparently be endangered due to the irregular water flow in the water courses to which it is tigthly bound. It has been used multivariate analysis techniques, to study the food of this species with the aim of determining in a more objective and realiable way the local, monthly and seasonal variations as well as the factors which provoke them.

\section{METHODS}

Study area. In order to determine the otter's diet in the Central Sierra Morena, two rivers: Guadalmez and Cuzna, belonging to different hydrographic basins; a stream: Garcia, which is a tributary of the river Cuzna, and the Sierra Boyera Reservoir, situated at the headwaters of River Guadiato (Fig. 1) were chosen. The climate of this zone, classified as Mediterranean sub-humid, provides a limited and highly irregular water flow, leaving the water concentrated, throughout the lengthy dry season (from the middle of May to the middle of September) in pools isolated one from the other.

Apart from the Sierra Boyera Reservoir, the three remaining sampling zones are situated in areas scarcely influenced by the human population, and where the Mediterranean type termophyle vegetation belonging to the Querceta ilicis (C.E.B.A.C., 1971) class predominates, whilst the riverbed of the waterways is protected by a thick maquia.

Analys is of spraints and data processing. The excrements were collected fortnightly in the four indicated zones, following a fixed course, from April, 1979 to March, 1980.

The cleaning of the scats was carried out following the method described by Webb (1976). The identification of the remains was carried out with use of guides, keys and by type collection created for this purpose, and which we based on the following structures: vertebrae, pharyngeal teeth, bone radii, jaw bones, preopercula and opercula bones, and on the extremities, scales, skins, feathers and exoskeletons of insects.

In order to present the data we have followed the method employed by Erlinge (1967, 1968 and 1969) and other authors (Stephens, 1967; Rowe-Rowe, 1977 c; Mason \& MacDonald, 1980; among others) in which the data are expressed as a percentage of the relative frequency of appearance. The remains of a prey found in an excrement are considered as belonging to a single captured specimen. The total captured prey of a certain species is given by the sum total of all scats containing the remains of the species.

The variation of the fish population in the area where the scats were collected in the Sierra Boyera Reservoir was carried out by means of sampling with nets - two trammel nets and two gill nets - which were checked every 12 hours in order to avoid saturation. The data obtained were converted by means of fishing effort index (Ricker, 1975), with two nets being used to avoid his selectivity. In order to measure the diet preference index of Ivlev (1961), in according to Cock (1978), was used:

$$
P=\frac{N e / S e-N / S}{N e / S e+N / S} \quad \text { where }
$$




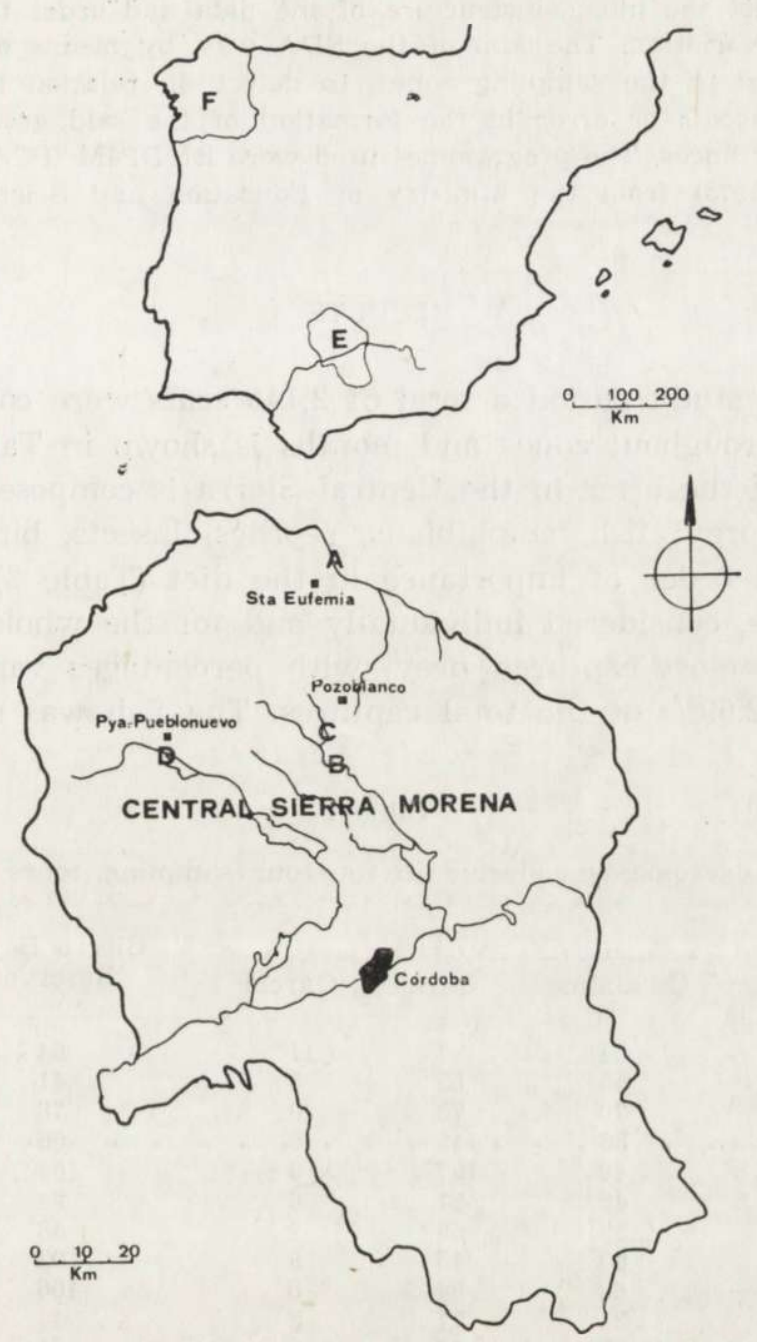

Fig. 1. Position of the province of Cordoba and of the four zones sampled. A: River Guadalmez, B: River Cuzna. C: García Stream. D: Sierra Boyera Reservoir. The letters $\mathrm{E}$ (Córdoba) and $\mathrm{F}$ (Galicia) indicate the places where, at the present time, the diet of the otter has been studied on the Iberian Peninsula.

$\mathrm{Ne}$ - is the number of prey type I eaten; $N-$ is the number of prey initially present; $S$ - the total number of prey eaten and $S-$ is the the total number of prey initially present.

As for the multivariant methods, the Principal Components Analysis (PCA) and the Stepwise Discriminant Analysis (SDA) were used to study the specimens collected in the four zones considered monthly and seasonally. The aim of PCA was to attain the ordering of the seasons and months, using the percentages of appearance of each category of prey in the different sampling areas as variables, 
in order to detect the internal structure of the data and order them into trends of independent variation. The aim of the SDA was, by means of the formation of apriori groups in the sampling zones, to detect, in relation to the prey, the percentage of success or error in the formation of the said groups and also to detect their differences. The programmes used were BMDP4M (PCA) and BMDP7M (SDA) (Dixon, 1975) from the Ministry of Education and Science programmes library.

\section{RESULTS}

During the study period a total of 2,145 scats were collected, whose distribution throughout zones and months is shown in Table 1.

The diet of the otter in the Central Sierra is composed of six main categories of prey: fish, amphibians, reptiles, insects, birds and mammals, listed in order of importance in the diet (Table 2), In the four sampling areas, considered individually and for the whole of the zone, fish were the most captured prey, with percentages varying between $70.56 \%$ and $82.69^{\circ} \%$ of the total captures. The fish was represented in

Table 1

The number of excrements collected in the four sampling zones in each month.

\begin{tabular}{|c|c|c|c|c|c|}
\hline \multirow{2}{*}{ Month } & \multicolumn{3}{|c|}{ Rivers } & \multirow{2}{*}{$\begin{array}{l}\text { Sierra Boyera } \\
\text { Reservoir }\end{array}$} & \multirow{2}{*}{ Total } \\
\hline & Guadalmez & Cuzna & García & & \\
\hline April & 34 & 1 & 11 & 64 & 110 \\
\hline May & 55 & 55 & 5 & 41 & 151 \\
\hline June & 70 & 73 & 0 & 78 & 221 \\
\hline July & 86 & 115 & 0 & 66 & 267 \\
\hline Aug. & 49 & 107 & 0 & 104 & 260 \\
\hline Sept. & 46 & 81 & 0 & 94 & 221 \\
\hline Oct. & 12 & 65 & 2 & 58 & 137 \\
\hline Nov. & 60 & 15 & 9 & 92 & 176 \\
\hline Dec. & 68 & 84 & 6 & 106 & 264 \\
\hline Jan. & 31 & 71 & 3 & 44 & 149 \\
\hline Feb. & 39 & 29 & 0 & 41 & 109 \\
\hline March & 47 & 18 & 0 & 15 & 80 \\
\hline Total & 597 & 709 & 36 & 803 & 2145 \\
\hline
\end{tabular}

the diet by three families: Cyprinidae, Centrarchidae and Cobitidae (in the García stream and the River Cuzna the Centrarchidae family did not appear). The first of these families provided the majority of the fish captures. Amphibians - all of the captures referring to Rana ridibunda - constituted the second important capture in the diet, except in the reservoir, where the birds took this place. Reptiles, especially Natrix maura, and insects too formed an important part in the diet. On the other hand, only few mammals were captured. 


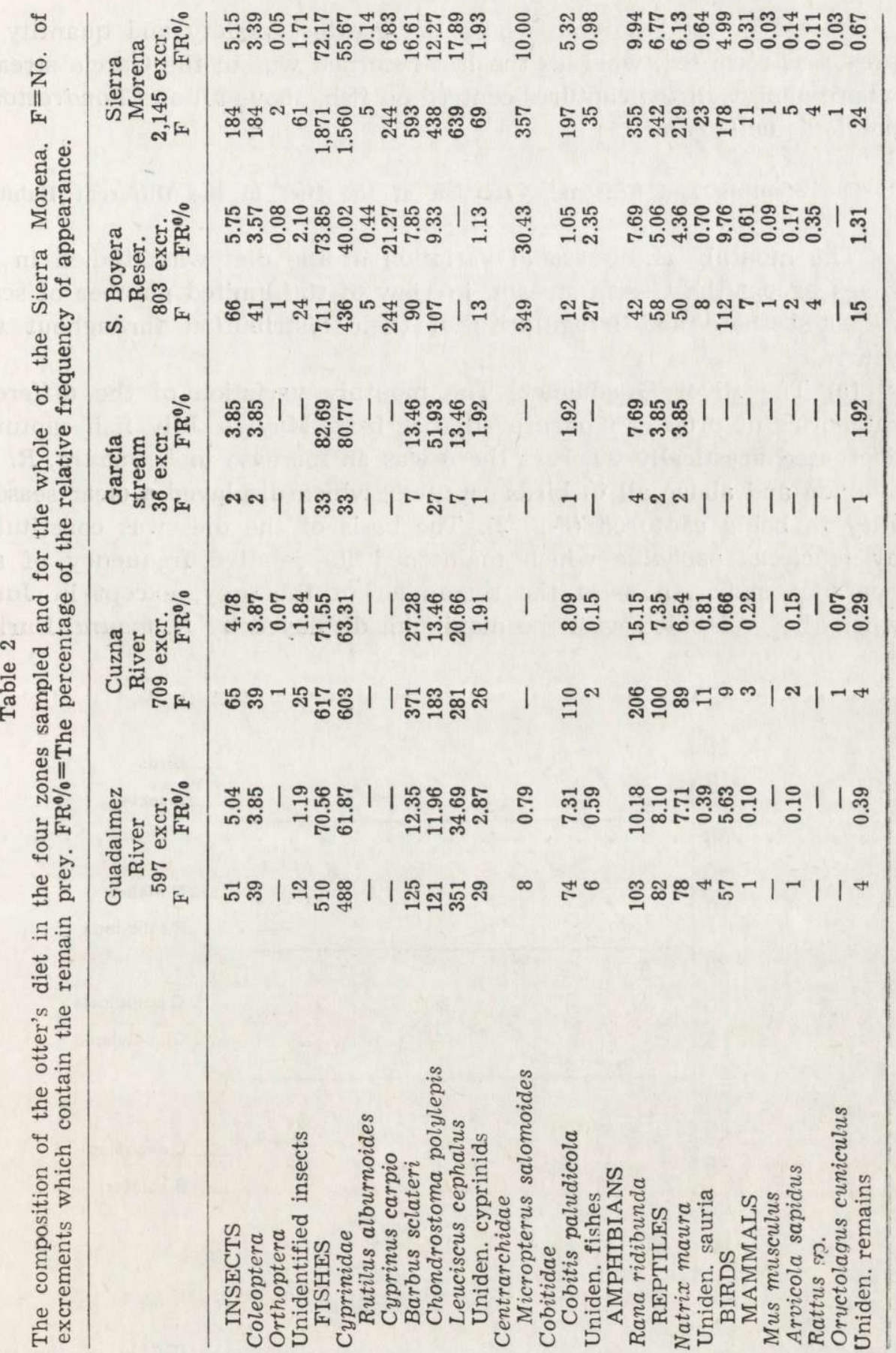


It was in the reservoir where the greatest variety and quantity of prey was recorded, whereas the last recorded was in the García stream, where almost all the captures centred on fish, above all on Chondrostoma polylepis willkommi.

1. The Monthly and Seasonal Variation of the Diet in the Different Habitats

The monthly and seasonal variation of the diet was studied in all zones except the García stream, in view of the limited number of scats collected there and irregularity of their distribution throughout the year.

(a) The River Guadalmez. The monthly variation of the different categories of prey can be proved that from May to July fish captures decreased drastically whereas there was an increase in $N$. maura, $R$. ridibunda and above all in birds captures, which displayed a clear seasonality in being captured (Fig. 2). The basis of the diet was constituted by leuciscus cephalus which maintened its relative frequency of appearance above those of the remainder of the prey, except in June, when they coincided with the maximum displayed by $N$. maura. During

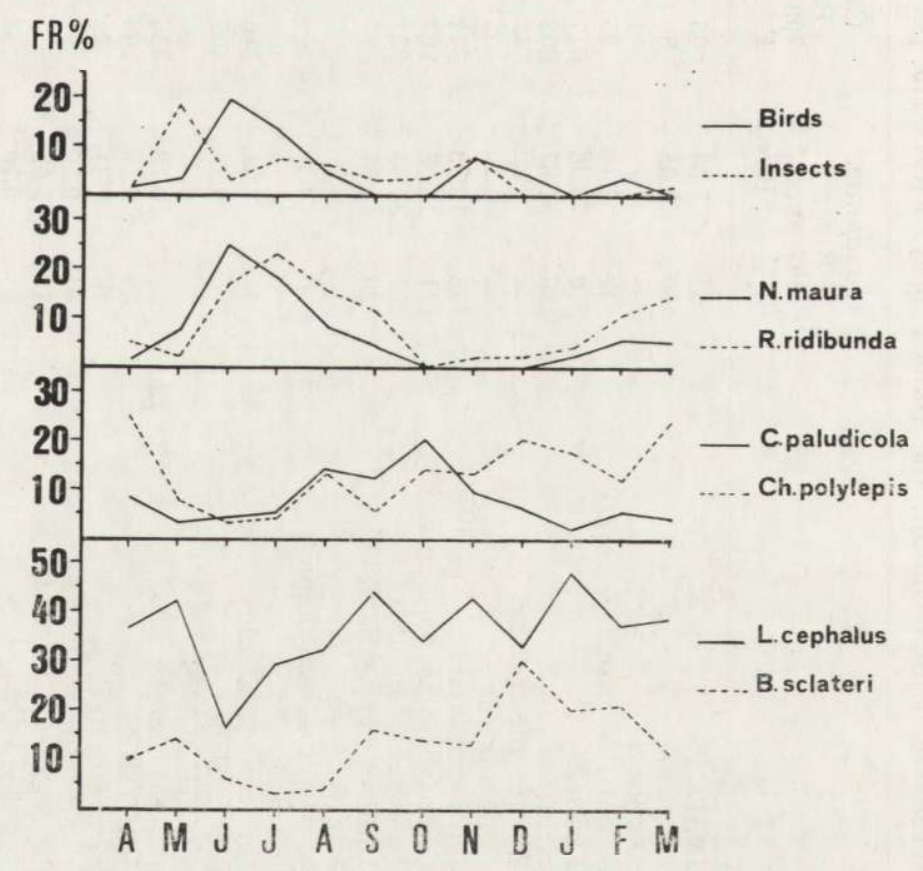

Fig. 2. The monthly distribution of the relative frequencies $\left(\mathrm{FR}^{\circ} \%\right)$ of the prey captured in the River Guadalmez. A. sapidus, M. salmoides and Sauria are excluded due to their limited percentage. 


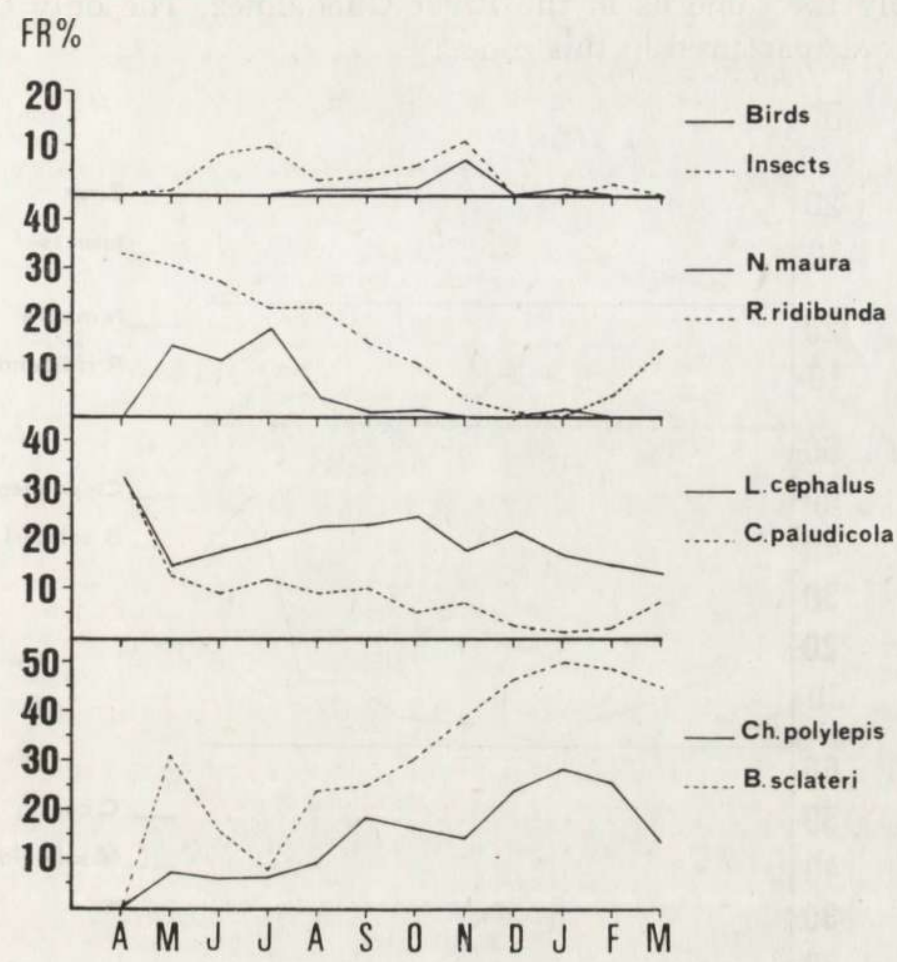

Fig. 3. The monthly distribution of $\mathrm{FR} \%$, of the prey captured in the River Cuzna. A. sapidus, O. cuniculus and Sauria are excluded because of their low FR\%.

a very definite period of time — from September to November - a limited quantity of Micropterus salmoides was captured. The greater part of $N$. maura, $R$. ridibunda, birds and insects captures took place at a time when the river levels were low.

(b) The River Cuzna. Just as the monthly variation occurred in the River Guadalmez, so too did it occur in the River Cuzna, and in this zone it took place in a more marked form (Fig. 3). As in the previous zone, $L$. cephalus maintained its relative frequencies of appearance fairly constant throughout the year. In general, the most important fish captures took place from August to March, although from April to June more Cobitis paludicola were captured. The dominant prey, with regard to fish, was Barbus sclateri, amounting to $50 \%$ of the total captured prey in January. In this zone birds were infrequent prey of the otter, appearing in a small proportion in the diet from August to January. $N$. maura and $R$. ridibunda were distributed throughout the year ap- 
proximately the same as in the River Guadalmez. The only Oryctolagus cuniculus was captured in this zone.

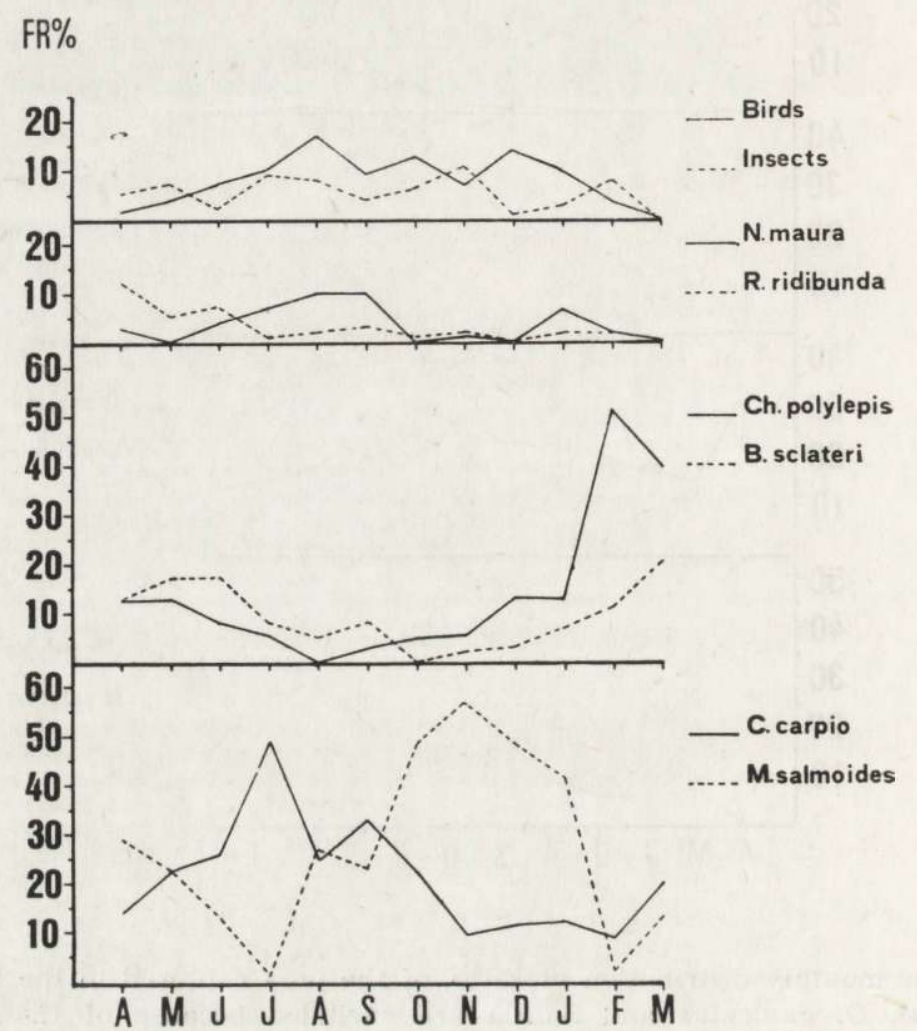

Fig. 4. The monthly distribution of $F R \%$ of the prey captured in the Sierra Boyera Reservoir. R. alburnoides, C. paludicola, Sauria and mammals are excluded because of their low $\mathrm{FR} \%$.

(c) The Sierra Boyera Reservoir. In the monthly variation of the relative frequencies of appearance of the different prey it has been observed that fish constituted the basis of the diet during the whole year (Fig. 4). When the frequency of appearance $(\mathrm{FR} \%)$ of a species decreased there was a corresponding increase in another, allowing the year to be divided up into three periods, in which dominated alternitavely Cyprinus carpio, $M$. salmoides and $C h$. polylepis willkommi. The rest of the fish species were captured in a smaller quantity. The rest of the vertebrates and insects which completed the diet were distributed with different frequencies throughout the year, without standing out particularity at any time, as occurred in the two zones dealt with previously. Birds were an exception, displaying higher frequencies in Summer and 
Autumn. It was in this zone that the highest capture percentages of birds and mammals was found, representing at the same time the greatest specific diversity.

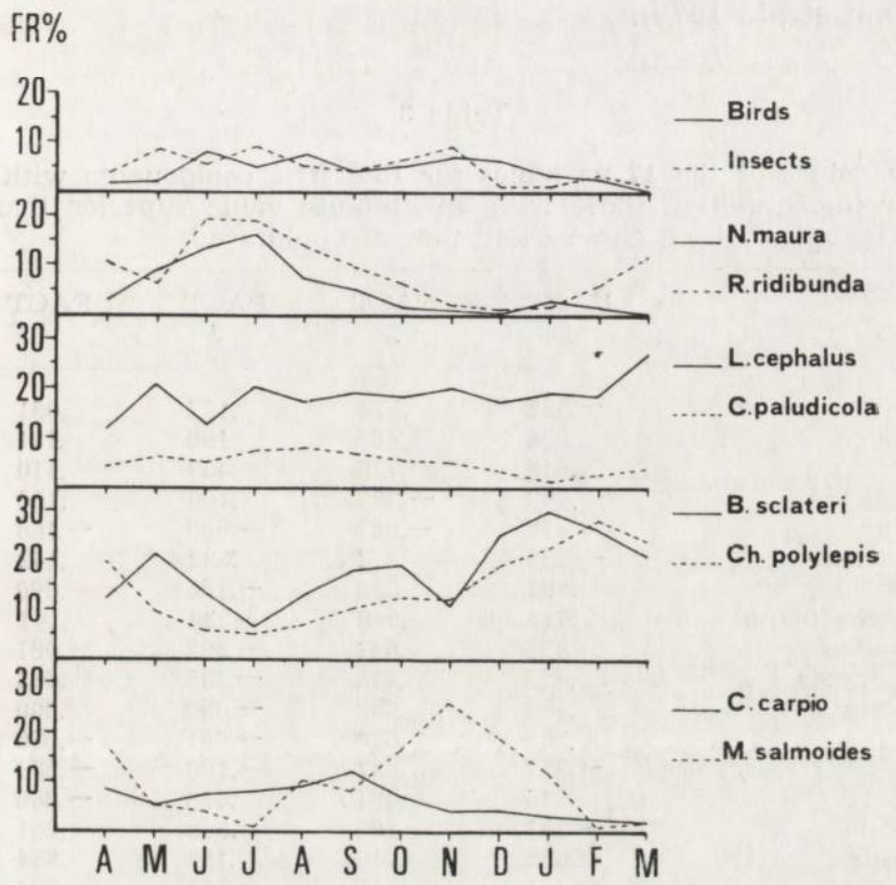

Fig. 5. The monthly distribution of $\mathrm{FR}^{\circ} \%$ of the prey captured during the study in the Central Sierre Morena. R. alburnoides, Sauria and mammals are excluded because of their low $\mathrm{FR}_{0} \%$.

(d) The Central Sierra Morena. For the whole of the Central Sierra Morena the monthly variation of the different species was subject to the distribution patterns which were displayed individually in the different areas considered (Fig. 5). For example, the frequency of appearance of fish as a whole, decreased at the time understood, between May and July, when the captures of $N$. maura and $R$. ridibunda increased. As occurred in the two rivers, the captures of $L$. cephalus were produced in a fairly stable way during the whole year. The limited captures of mammals occurred from April to September.

\section{Comparison of the Diet in the Different Sampling Zones}

(a) Monthly variation. For the samples of the diet considered monthly - with the exception of the Garcia stream which produced a limited amount of excrements - the PCA acquired in the first five 
axes $75.9 \%$ of the total accumulated variance (Table 3 ), with $28.0 \%$, $18.1 \%$ and $12.7 \%$ corresponding respectively to the first three axes. The adequacy mean of the samples gathered was 0.57 (Dziuban \& Shirkey, 1974; Dziuban et al., 1979).

\section{Table 3}

Non rotated factors of the 17 variables for five first components with considered monthly. For interpretation those with an absolute value superior than 0.50 have been chosen, and they are boldfaced.

\begin{tabular}{|c|c|c|c|c|c|}
\hline Variables & $\begin{array}{c}\text { FACT } \\
1\end{array}$ & $\underset{2}{\text { FACT }}$ & $\underset{3}{\mathrm{FACT}}$ & $\underset{4}{\text { FACT }}$ & $\underset{5}{\text { FACT }}$ \\
\hline 1 C. carpio & -.552 & .672 & .127 & .051 & .184 \\
\hline $2 M$. salmoides & .553 & .433 & .190 & .171 & .526 \\
\hline 3 B. sclateri & .618 & -.126 & .477 & .110 & .370 \\
\hline 4 C. polylepis & .462 & -.306 & .400 & .150 & .480 \\
\hline $5 \mathrm{~L}$. cephalus & .873 & -.083 & -.085 & -.166 & .024 \\
\hline $6 R$. alburnoides & -.288 & .477 & .682 & .142 & -.345 \\
\hline 7 C. paludicola & .861 & .232 & -.134 & -.090 & .035 \\
\hline 8 Unidentified ciprinids & .644 & .010 & .230 & .141 & -.330 \\
\hline 9 Natrix maura & .471 & .647 & -.392 & -.081 & -.252 \\
\hline 10 Unident. Sauria & .325 & .410 & -.135 & 683 & .006 \\
\hline $11 R$. ridibunda & .802 & .452 & -.090 & .000 & -.038 \\
\hline 12 Insects & .365 & .620 & -.401 & -.070 & .036 \\
\hline 13 Birds & -.357 & .637 & -.180 & -.286 & .303 \\
\hline 14 A. sapidus & .225 & .421 & .618 & -.366 & .030 \\
\hline 15 Rattus sp. & -.251 & .487 & .568 & -.251 & -.215 \\
\hline 16 M. musculus & -.652 & .210 & .152 & .854 & -.064 \\
\hline 17 O. cuniculus & -.451 & -.147 & -.263 & .084 & -.465 \\
\hline Variance, $\%$ & 28.0 & 18.1 & 12.7 & 9.6 & $\begin{array}{r}7.5 \\
75.9\end{array}$ \\
\hline Cummulative variance, $\%$ & 28.0 & 46.1 & 58.8 & 68.4 & 75.9 \\
\hline
\end{tabular}

After rotation, the existence of three groups was shown on the graph defined axes I and II (Fig. 6A). One group characterized by its strong positive polarity around axis I and which is composed of the species which displayed a greater frequency in the dry seasons of the rivers, formed by: $R$. ridibunda, $N$. maura, $C$. paludicola and insects. A second group composed of the variables which gather together with high values on axis II and are prey were more abundantly present in the excrements gathered in the reservoir, formed by: $C$. carpio, $M$. salmoides and birds. Finally a thrid group formed of the variables with cluster together around the coordinates centre and in which appear prey which were found together and with greater regularity in the rivers and reservoir.

The months are separated into three groups by PCA (Fig. 6B): one group (G. 1), separated from the rest by axis I, is constituted of the months in which the rivers offered less water and is dominated by the prey with high values on axis I ( $R$. ridibunda, N. maura, $C$. paludicola 
A)

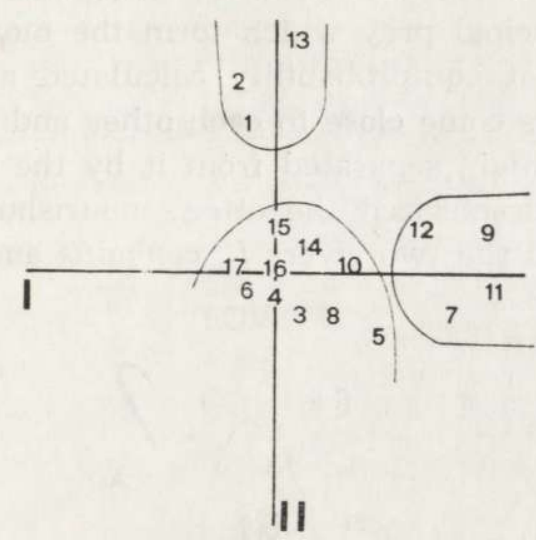

B)

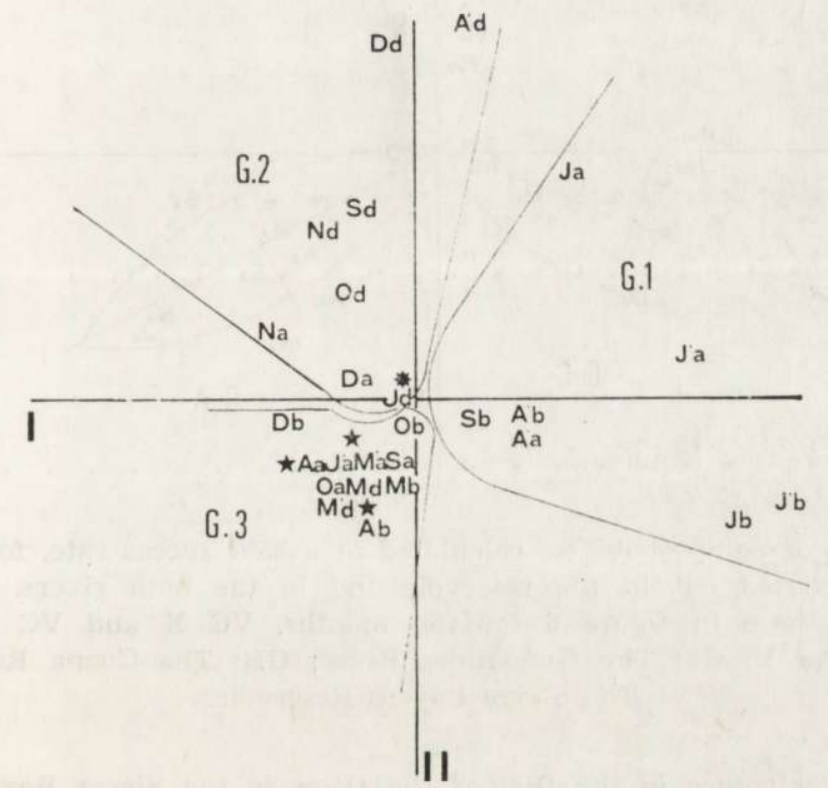

Fig. 6. The ordering of the prey (A) and the months (B) by means of PCA on axes I and II, excluding the Garcia Stream. The prey are expressed as in Table 3. The months are indicated with two letters: the capital corresponding to the month (March, July and August have an apostrophe) and the second letter to the River Guadalmez (a), River Cuzna (b) and Sierra Boyera Reservoir (d).

and insects). Another group is principally formed during autumn and spring of the reservoir, and in which dominated by C. carpio, M. salmoides and birds. The third group is formed by the rest of the months (G. 3) and is dominated by l'ess characteristic prey for each zone. 
(b) Local variation. The SDA (Fig. 7) distinguishes the three functional zones from the principal prey which form the monthly diet in each of them. The ellipses of equiprobability calculated at $95 \%$ success rates, reveal that the rivers come close to each other and to the reservoir, and, at the same time remain separated from it by the canonical variable Y. The prey which characterized the otter's nourishment in the reservoir was $C$. carpio and in the two rivers $L$. cephalus and B. sclateri.

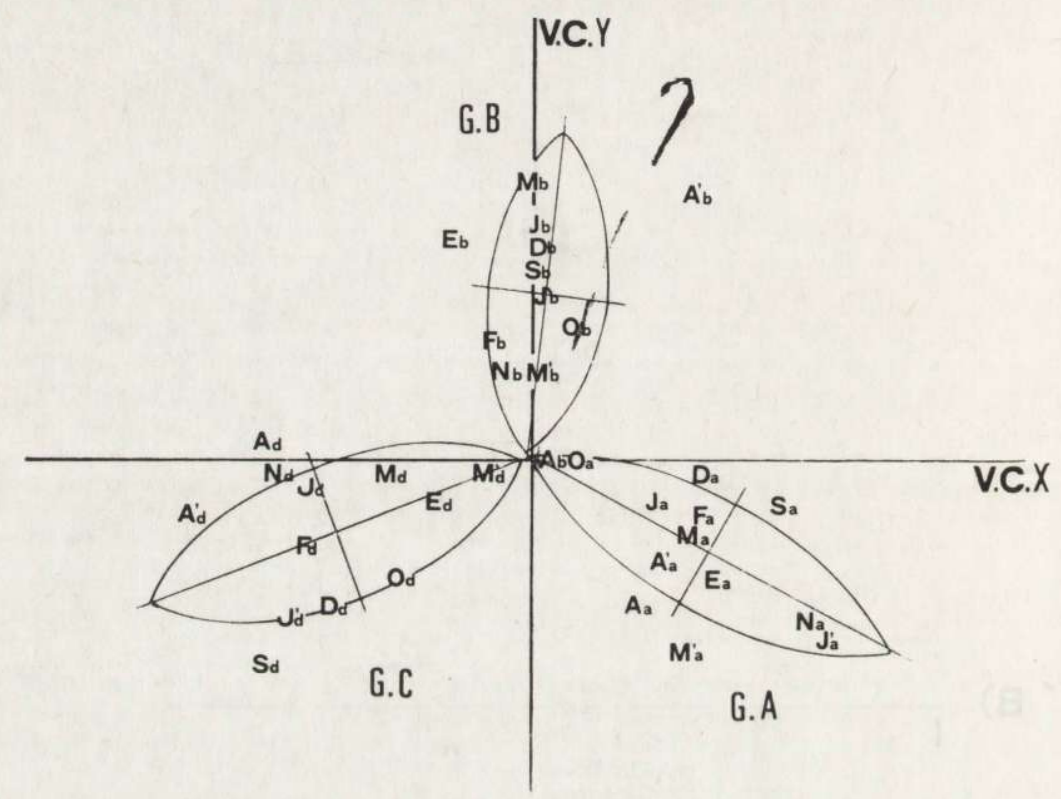

Fig. 7. Ellipses of equiprobability, calculated at a $95 \%$ succes rate, for the months of sampling carried out in the reservoir and in the both rivers. The symbols correspond to those in figure 6 for the months. VC X and VC Y: Canonical variables $\mathrm{X}$ and $\mathrm{Y}$. Ga: The Guadalmez River; GB: The Cuzna River and GC: The Sierra Boyera Reservoir.

\section{The Food Preference in the Diet of the Otter in the Sierra Boyera Reservoir}

The food preference in the otter's diet, with regard to fish, has been studied in the Sierra Boyera Reservoir, following the evolution of the fish population, by means of sampling with nets, throughout the study year (Table 4) and it has been compared by the otter in this place during the same period of time (Table 4B) (Erlinge, 1967; Wise et al., 1981).

The annual fluctuation in the $C$. polylepis population, the most abundant species in the reservoir, was evident, and there existed a period, June to August and November, when no capture of this species took place with nets. The $M$. salmoides population was maintened regularly 


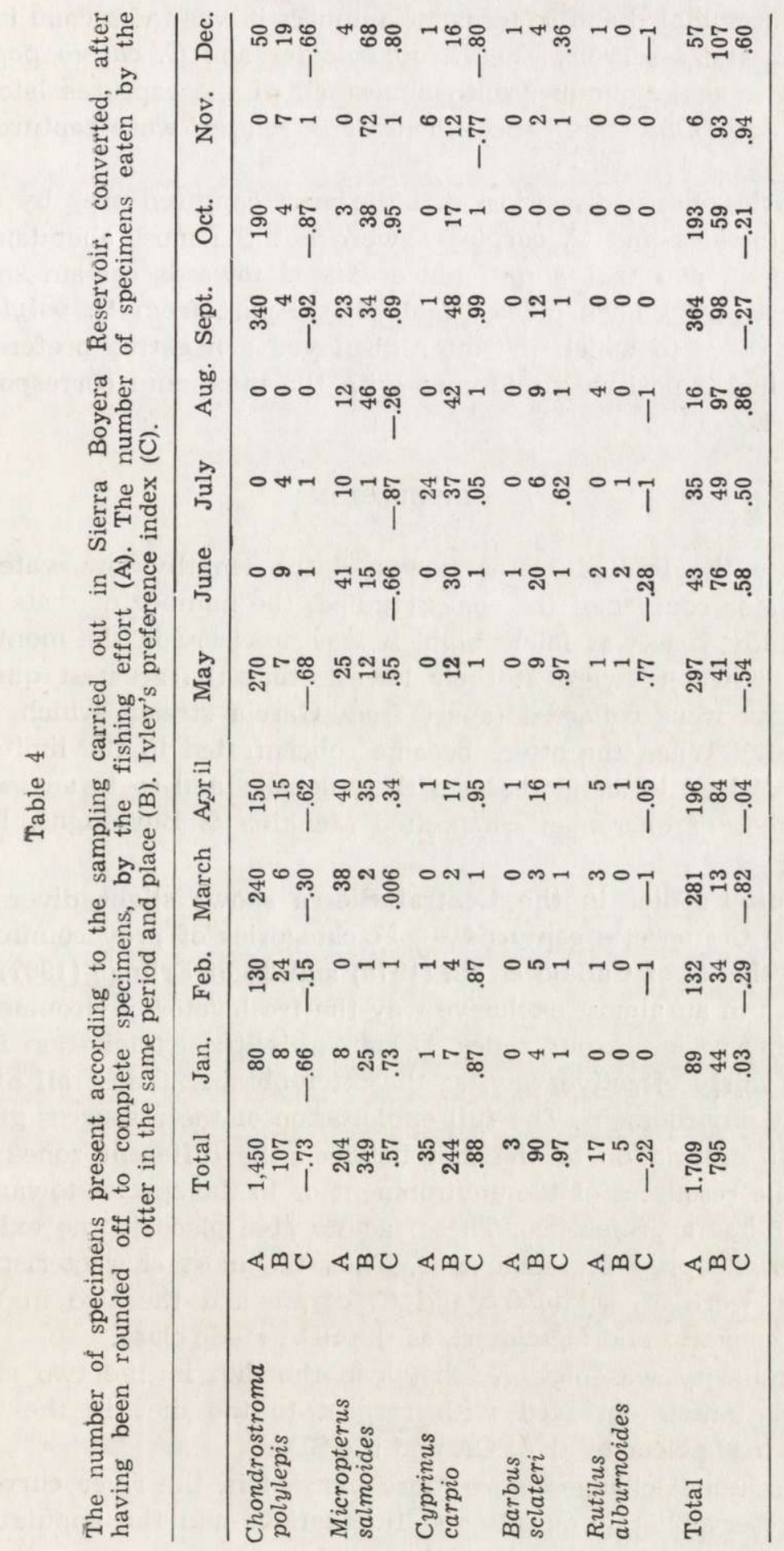


in the zone sampled and in terms of numbers it was the second important species in the reservoir. The $R$. alburnoides and $C$. carpio populations appeared in l'esser number with almost all of the captures later taking place in July. Only three speciemens of B. sclateri were captured in the year.

It can be observed a priori that the most captured prey by the otter - M. salmoides and C. carpio - were not the most abundant in the environment, and that a preference existed towards certain species, as made clear by Ivlev's index (Table 4C). Apart from C. polylepis and $R$. alburnoides to which the otter displayed a negative preference, the remains had a positive preference with the maximum corresponding to B. sclateri.

\section{DISCUSSION}

Despite the limited water flow and the lengthy low water period in the water courses of the zones studied, the number of scats gathered in the study year was fairly high. It was precisely in the months when the rivers' waters were at their lowest, that the greatest quantity of excrements were collected (apart from Garcia stream which dried up completely). When the otters became concentrated in the limited water zones, this lead to an increase in their density and so to an increase in the number of excrements deposited (Jenkins \& Burroughs, 1980) and collected.

The otter's diet in the Central Sierra shows slight diversity with regard to the species captured -17 categories of prey counted as opposed to the 33 of Callejo et al., (1979) and 28 of Erlinge (1967) - since it exploits in an almost exclusive way the freshwater environment which is poor in species in our zones. Despite this, the exploitation is carried out in a fairly effective way, as the otter obtains almost all of its food from this environment. The full exploitation of the resources gives place to the differentiation of the diet between the different zones sampled, due to the resources of the environment or to the species towards which the otter has a preference. These factors give place to the existance of characteristic prey for each zone. Thus the most characteristic in the reservoir were $M$. salmoides and $C$. carpio and the two in the river were $L$. cephalus and B. sclateri, as the SDA made clear.

A similarity was observed between the diet in the two rivers and a differentiation observed with respect to the diet in the reservoir, which is made clear by the PCA and the SDA.

The seasonal changes were more marked in the river currents than in the reservoir. But despite the fluctuations and the populational dy- 
namics which certain animals displayed and which had an influence on the composition of the diet when the number of possible prey varied (Wise et al., 1981), the scarcity of water in the water currents had a decisive influence on the diet. In the Sierra Boyera Reservoir, since the quantity of water is almost constant, it does not have an influence upon the fish populations, nor upon those of other prey, and its density of specimens is due to their dynamics, biology or other factors. When Spring and Summer arrived, the number of amphibians and reptiles increased and the early elements in the birds and mammals populations appeared which lead to potential prey increase for the otter. The diet was enriched by other prey besides fish, but without the quantity of fish captures being diminished in such considerable way as in the rivers, since the density of these new prey was limited when compared with the density of fish and with the great volume of water in the reservoir.

In the rivers, the scarcity of water in the low water period and the formation of isolated pools, compelled the fish to migrate to free zones or, as occurred with the remaining categories of prey, to become concentrated in these pools. The inferior swimming abilities of $R$. ridibunda and $N$. maura compared to those of fish, made them more easily captured by otter (Erlinge, 1968) which found an important source of food in them during this period.

The greatest insects captures were all beetles, with the exception of two Grillotalpa grillotalpa. These insect capture together with captures of $R$. ridibunda and $N$. maura were produced precisely in the low water period when advantage was taken, as we have already stated, of the great concentration of the latter in the limited water zones.

Reptiles constituted an important prey in the otter's diet in the Central Sierra Morena, where the highest percentages of reptile captures were found, with those of Callejo et al., (1979) being somewhat smaller in Galicia. This constitude a differentiating feature in the diet on the Iberian Peninsula with respect to the rest of Europe.

The results obtained from the birds present a greater difficulty of interpretation, since the food remains could not be identified in their entirety. Nevertheless the presence of feather belonging to Anas platyrhynchos, Gallinula chloropus and Fulica atra could be detected. The River Cuzna and García Stream, offer limited open zones and few aquatic birds and, because of this, the captures were limited or null. On the other hand they were more plentiful in the River Guadalmez and the Sierra Boyera Reservoir where the captures had greater importance. The movements and migrations of the birds and the appearance of early elements in the populations (Wise et al., 1981) had an influence on the captures which caused their seasonality. 
Mammals are an occasional prey of the otter in the Central Sierra Morena as is demonstrated by the limited percentage in which they appeared in the diet, which contrast with the $13,3 \%$ obtained by Cajello et al., (1979) in Galicia, the highest for the whole Lutra genus. As occurs with reptiles and amphibians the preference towards aquatic species is evident, since the majority of the captures were centred upon A. sapidus and Rattus sp., which prowl near the bank, among the reeds and bulrushes of the reservoir - the place where the capture of the latter originated. The limited number of mammals captured may be due, in part at least, to competition with other mammals, especially Vulpes vulpes, which are plentiful' in the zone (Erlinge, 1969 and 1972; Jenkins \& Harper, 1980; Wise et al., 1981).

Fish, considered both as separate species, and together, represented the most important prey in the otter's diet in any period of the year, although they were subject to monthly and seasonal variation. It was in the rivers where the greatest difference between the quantity of fish captured in the dry season and the wet season was registered, because of the reasons already explained. For the whole of the Central Sierra Morena the same phenomenon was observed.

In the diet of otters in both rivers the regular presence of $L$. cephalus stood out throughout the whole annual cycle. This is due to the fact that this species is a particular exploiter of the river's habitats. The most captured fish in the River Cuzna was B. sclateri since the otter takes advantage of the concentrations of this fish in the deep pools on this river's bed (B. sclateri foods from riverbeds), whereas the River Guadalmez does not offer any of these pools. It was noticed in both rivers that C. carpio was not present which may be due to the fact that this species is characteristic of still, deep waters (Castello, 1980). The presence of some $M$. salmoides captures in the River Guadalmez was probably due to the fact that they moved up from the nearby Zujar Reservoir, where they had been introduced artificially to exploit the river's food resources.

The remaining species which complete the diet displayed fluctuations which are probably due to the particular biology and dynamics of the fish populations, unknown at this time on the Iberian Peninsula.

Although $C$. polylepis was the most abundant species in the reservoir, $M$. salmoides and $C$. carpio were the most eaten. Moreover, a clear preference existed towards $B$. sclateri, together with the existance of three periods in the year, with each one dominated by one species. This makes it clear that the most captured prey was not always the most abundant in the environment (Erlinge, 1967; Frined, 1978). The causes for the preferred capture of a certain prey and the monthly fluctuations include factors such as the biology and dynamics of the prey (Erlinge, 1967; 
Callejo et al., 1979; Wise et al., 1981) the greatest vulnerability and least ability to escape, their activity, the size of the fish (Erlinge, 1967; Rowe-Rowe, 1977a, b; Jenkins et al., 1979), the situation of the prey (Wise et al., 1981) and the clarity and temperature of the water (RoweRowe, 1977a, b).

We can sum up be saying that in the Central Sierra Morena both seasonal and monthly variations were observed which were produced in the same way as those observed in Great Britian (Jenkins et al., 1979; Jenkins \& Harper, 1980; Wise et al., 1981) and in Sweden (Erlinge, 1967) but in a contrary way to those which occurred in Galicia (Callejo et al., 1979).

A local variation could be observed too between the otter's food in the rivers and in the reservoir, which was due to the seasonal variation and to the prey caused principally by amphibians and reptiles, and to the existence of dominant or characteristic prey in the diet of each area. The composition of the diet in our zone is influenced by several factors: (1) The availability of the resources, as is shown by the exploitation of the prey which displayed a marked seasonality and the existence of dominant prey in the diet, which coincided with their abundance in the environment. (2) The preference towards certain species $-B$. sclateri, $C$. carpio and $M$. salmoides - as was evident in the case of the reservoir. (3) The seasonality which certain prey displayed and which gave place to a seasonal variation in the diet. (4) The irregular system of the rivers, which creates a concentration of certain species in the zones with water. (5) The dynamics and biology of the prey populations.

Acknowledgements: The authors wish to be express their gratitude to Prof. Dr. Carmen Bach and Dr. Miguel Delibes for their interesting suggestion after the critical reading of the manuscript, to D. Carlos Fernandez-Delgado for his help and also to the University of Seville's Centro de Cálculo (Calculation Centre) for the help given in the data processing.

\section{REFERENCES}

1. Callejo A., Guitian J., Bas S., Sánchez J. L. \& Castro A., 1979: Primeros datos sobre la dieta de la nutria, Lutra lutra (L.), en aguas continentales de Falicia. Donana, Act. Vert., 6: 191-202.

2. Castelló V., 1979: Ictiofauna del río Guadiato: Estudio de la población de barbos (B. barbus sclateri Stein.). Memoria de Licenciatura. Universidad de Córdoba. Córdoba. 54 pp.

3. C.E.B.A.C., 1971: Estudio agrobiológico de la provincia de Córdoba. Madrid: $1-401$.

4. Cock M. J. W., 1978: The assessment of preference. J. Anim. Ecol. 47: 817-832. 
5. Dixon W. J., 1975: BMDP. Biomedical Computers Programs. University of California Press. Berkeley. Los Angeles.

6. Dziuban Ch. D. \& Shirkey E. C., 1974: When is a correlation matrix appropiate for factor analysis? Psychol. Bull., 81: 358-361.

7. Dziuban Ch. D., Shirkey E. C. \& Peeples T. O., 1979: An investigation on some distributional characteristics of the measure of sampling adequancy. Educ. Psychol., Measurement, 39: 534-549.

8. Erlinge S., 1967: Food habits of the Fish-otter, L. lutra L., in South Swedish habits. Viltrevy, 4: 371-438.

9. Erlinge S., 1968: Food studies on captive otters (L. lutra L.). Oikos, 19: $259-270$.

10. Erlinge S., 1969: Food habits of the otter (L. lutra L.) and the mink (M. vison) in Sweden, Oikos, 20: 1-7.

11. Erlinge S., 1972: Interspecific relations between otter (L. lutra) and mink (M. vison) in Sweden. Oikos, 23: 327-335.

12. Fairley J. S., 1972: Food of otters (Lutra lutra) from Co. Galway, Ireland, and notes on other aspects of their biology. J. Zool., Lond., 166: 469-474.

13. Fairley J. S. \& Wilson S. C., 1972: Autumn food otters (Lutra lutra) on the Agivey River, County Londonderry, Northern Ireland. J. Zool., Lond., 166: $468-469$.

14. Fiend G. R., 1978: A comparison of predator scat analysis with conventional techniques in a mammal survey of contrasting habitats in Gippsland, Victoria. Aust. Wildl. Res., 5: 75-83.

15. Hewson R., 1973: Food and feeding habits of otters Lutra lutra at Loach Park, north-east Scotland. J. Zool., Lond., 170: 159-162.

16. Jenkins D. \& Burrows G. O., 1980: Ecology of otters in Northern Scotland: III. The use of faeces as indicator of otter ( $L$. lutra) density and distribution. J. Anim. Ecol., 49: 755-774.

17. Jenkins D. \& Harper R. J., 1980: Ecology of otters in Northern Scotland: II. Analysis of otter ( $L$. lutra) and mink (M. vison) faeces from Deeside, NE Scotland in 1977-78. J. Anim. Ecol., 49: 737-754.

18. Jenkins D., Walker J. G. K. \& McCowan D., 1979: Analyses of otter (Lutrc lutra) faeces from Deeside, NE Scotland. J. Zool., Lond., 187: 235-244.

19. Ivlev V. S., 1961: Experimental ecology of the feeding of fishes. Yale University Prees. New Haven.

20. Mason C. F. \& MacDonald S. M., 1980: The winter diet of otter (Lutra lutra) on a Scottish sea loch. J. Zool., Lond., 192: 558-561.

21. Ricker W. E., 1975: Computation and interpretation of biological statistics of fish populations. Bull. Fish. Res. Boars. Can., 191: 1-382.

22. Rowe-Rowe D. T., 1977a: Prey capture and feeding behaviour of South African otters. The Lannargeyer, 23: 13-21.

23. Rowe-Rowe D. T., 1977b: Variations on the predatory behaviour of the clawles otter. The Lammargeyer, 23: 22-27.

26. Rowe-Rowe D. T., 1977c: Food ecology of atters in Natal, South Africa. Oikos, 28: $210-219$.

27. Stephens M., 1957: The natural history of the otter. Tumbridge Wells. Kent.

28. Webb J. B., 1975: Food of the otter (Lutra lutra) on the Somerset levels'. J. Zool., Lond., 177: 486-491.

29. Webb J. B., 1976: Otter spraint analysis. An occasional publication of the Mammal Society. London. 
30. Wise M. H., Linn I. J. \& Kennedy C. R., 1981: A comparison of the feeding biology of mink, Mustela vison, and otter, Lutra lutra. J. Zool., Lond., 195: $181-213$.

Accepted, June 30, 1984.

\section{Pedro LOPEZ-NIEVES \& José A. HERNANDO Casal \\ STOSUNKI POKARMOWE WYDRY W CENTRALNEJ SIERRA MORENA (KORDOWA, HISZPANIA)}

\section{Streszczenie}

Badania nad składem pokarmu wydry, Lutra lutra (Linnaeus, 1758) prowadzono na podstawie analizy kału. Materiał zbierano nad brzegami rzek Guadalmez i Cuzna, strumienia Garcia oraz wokół zbiornika wodnego Sierra Boyera, w Centralnej Sierra Morena (Tabela 1; Ryc. 1). Jeżeli chodzi o rodzaj pokarmu, dieta wydry była mało zmienna i składała się z ryb, płazów, gadów, owadów, ptaków i ssaków (Ryc, 2-5). W czterech badanych strefach wystąpiły jednak pewne sezonowe różnice w składzie diety (Tabela 2, 3). W okresie obfitującym w deszcze, główne źródło pokarmu stanowią ryby, których udział znacznie zmniejsza się, gdy wody zaczyna być mało. Zmiany sezonowe diety oceniono przy pomocy analizy komponentów głównych i stwierdzono, że są one znacznie wyraźniejsze w rzekach niż w zbiorniku wodnym (Ryc. 6). Przy pomocy tego samego testu oraz analizy dyskryminacyjnej, oszacowano różnice w pokarmie wydr żyjących w badanych rzekach i na zalewie wodnym (Ryc. 7). Skład żeru uwarunkowany jest głównie jego dostępnością oraz wybiórczością wydry w stosunku do pewnych gatunków (Tabela 4). 